\title{
Türkiye'ye İlişkin Sosyal Boyutlu Deprem Yazınına Eleştirel Bir Bakış
}

\begin{abstract}
Oya AÇIKALIN ${ }^{1}$
Öz

Bu makale, ikincil veri analizine dayanan bir araştırmanın sonuçlarını paylaşmaktadır: Türkiye üzerine sosyal boyutlu deprem çalışmalarından daha önce derlediğim kapsamlı bir veri tabanındaki 139 metni amaçsal olarak seçip, literatürün eleştirel analizini yaptım; metodolojik konulara ağırlık verdim. Deprem çalışmaları alanında bu kapsamda bir sosyal veri tabanının kurulması kadar, oradaki metinlerin metodolojik yönden analizleri de henüz gerçekleştirilmemiş bilimsel çabalardandır. Ancak bu metnin asıl amacı, Türkiye'deki deprem çalışmaları alanında kurumsallaşmaya; bilim topluluğunun ve söylemin kuruluşuna katkıda bulunmaktır. Bu anlamda bu araştırmanın ilgili olduğu temel sosyoloji alanlarından biri bilim/bilgi sosyolojisidir. Şöyle ki; bir bilim alanının kurumsallaşması, o alandaki "paradigma" benzeri yapıların varlığıyla, yani teorik ve metodolojik ilkelerin, sorun tanımlarının, yenilik tanıtımlarının, eleştiri ve tartışmaların sistemli şekilde üretilmesiyle ilgilidir. Dolayısıyla kurumsallaşma, o alanda çalışanlara hitap eden bir topluluğun ve bir söylemin kuruluşuyla şekillenir. Bunların eksikliğinde, çok disiplinli (hatta disiplinler ötesi) bir alan olması gereken deprem çalışmalarının afet risk yönetimine kamusal etkisi zayıf kalır; Türkiye'deki durum da budur. Bu makale, var olan bilgi birikiminin, zamansal, mekansal ve hedef gruplar bakımından karşılaştırmalar yaparak sorunları ve çözümlerini daha derinlikli şekilde anlamamıza yeterince yardımcı olmadığına dair somut kanıtlar sunmaktadır. Bu sonuç, kısmen, araştırmaları, toplumun dirençlilik düzeyine katkı yapacak bir kolektif gündemle değil de, krizlerin tetiklemesiyle gerçekleştirmemizle alakalıdır. Önerilerim; birbirimize yönelik olumlu ilgimizi yoğunlaştırıp sürekli kılmamız, metodolojik ve teorik bilgi eksiklerimizi tamamlarken, doğa ve sosyal bilimler arasındaki ilişkisizliği ve hiyerarşiyi de sarsacak şekilde kapasite gelişimine önem vermemizi içermektedir. Makale, dergi çevrelerinin, disiplinler-ötesiliğe ve afet risk yönetimindeki sosyal boyutlara gerçekten sahip çıktıkları ölçüde, afet çalışmaları alanının ihtiyaç duyduğu eksiklerin giderilmesine olanak yaratma potansiyeli taşıdıklarına da işaret etmektedir.
\end{abstract}

Anahtar Kelimeler: Bilim/bilgi topluluğu, deprem/afet çalışmaları, sosyal boyut, metodoloji

\section{A Critical Assessment to Literature on Socially Oriented Earthquake Studies in Turkey}

\begin{abstract}
This article presents results of research based on secondary data analysis. I critically analyse the literature while paying particular attention to methodological issues. Both establishing a comprehensive data set on social dimensions of earthquake experiences and its methodological analysis are unique attempts in the literature. The main objective of this article is to contribute to the institutionalization of disaster studies in Turkey, as such it belongs also to the sociology of science/knowledge literature. The institutionalization of a scientific field requires that theoretical and methodological principles, formulation of problems, presentation of innovations, criticisms and discussions are produced and updated systematically, thus constructing the community as well as its discourse. When such outcomes are not achieved in the earthquake/disaster studies, the influence of the field on disaster risk management practices remains low. The findings presented in this article provide evidence that the accumulated knowledge does not help us understand problems and solutions adequately by making comparisons across time, space and target goups. This outcome is partly related to an approach that research is conducted mainly when crises have occured without relating it with a collective agenda prepared for improving societal resilience. Better capacity building mechanisms are needed accompanied with paying more positive interest to each other's work systematically, upgrading methodological and theoretical knowledge and skills, establishing better communication between social and natural sciences. Scientific journals have potentials to create opportunities to overcome insufficiencies observed in the field if trans-disciplinary approach and social dimensions of disaster risk management are adopted seriously.
\end{abstract}

Keywords: Scientific community, earthquake/disaster studies, social dimension, methodology

\footnotetext{
${ }^{1}$ Karamanoğlu Mehmetbey Üniversitesi, Sosyoloji Bölümü, İlgili yazar / Corresponding author: oacikalin@gmail.com Gönderim Tarihi: 23.11.2018

Kabul Tarihi: 25.12.2018
} 


\section{Giriş}

Türkiye'nin 70 yıllık sosyal bilimler birikimini değerlendiren Türkiye Bilimler Akademisi derlemesinde Akşit (1997) sosyologların öz-düşünümsel şekilde yani içe bakışla kendilerini anlayıp eleştirmeyi, alanlarını geliştirmenin bir yolu olarak önemsediklerini belirtmişti. Bu çizgi sonraki otuz yıl boyunca Türkiye'de sosyolojiden eksik olmadı, ama oluşmakta olan "deprem sosyolojisi" veya "deprem çalışmaları" alanlarında pek var olmadı da; belki bu noktaya gelmek biraz birikim gerektiriyordu.

"Deprem çalışmaları" derken, depremin sosyal boyutlarına odaklanan disiplinler-üstü veyaötesi bir "alan"dan söz ediyorum. Henüz böyle bir alanın varlığından söz etmek için erken olabilir, ama yazında bunun gerekliliği vurgulanıyor ve giderek bu yönde atılan adımlar artıyor. Bu yöndeki en umut verici gelişme, Aralık 2017'de yayın hayatına başlayan Dirençlilik (Resilience) Dergisi'dir. Öz-düşünümsel yaklaşım, deprem çalışmaları alanının temel özelliklerinden biri olmalı ve bu doğrultuda titiz, sebatkâr ve kolektif şekilde çaba göstermeliyiz. Bu düşünceyle aşağıda, daha önce oluşturduğum bir veri tabanını tanıtıp, o veri tabanının özelliklerine dayanarak deprem çalışmaları yazınını irdeleyeceğim.

Sözünü ettiğim veri tabanına dayalı ilk analizimde (Açıkalın 2017a), depremleri izleyen dört dönemde (akut, iyileşme, yeniden yapılanma ve hazırlık) Türkiye'nin yüz yıla yaklaşan deneyimini, bulabildiğim örnekleri kullanarak betimledim. Ortaya çıkan bir çeşit sosyal tarih anlatısı çerçevesinde, depreme dirençli-dirayetli bir toplum olma idealinin hangi noktasında durduğumuzu, yeni adımların neler olabileceğini, hangi koşullarda gerçekleşebileceğini ve neden gerçekleşmediğini tartıştım. Kullandığım metinlerin içeriği veya metodunu eleştirel şekilde değerlendirmedim; her metinden olabildiğince fazla yararlanıp, deprem çalışmaları yazınının parçalı yapısını aşmayı (bulgulardaki benzerlik ve farklılıkları belirleyerek, olgunun yapısını ve değişme eğilimlerini belirlemeyi) denedim.

Yaklaşımımda, psikoloji ve eğitim alanlarındaki pozitivist araştırmalarda daha sık rastladığımız "meta-analiz"in mantığına uyan yanlar vardı, çünkü birçok küçük, dağınık, kenarda kalmış çalışmayı bir araya getirip, anlamlı bir bütünlük yaratmayı denedim. İstatistiksel analiz ile daha güvenilir sonuçlar üretmeye olmasa bile, daha geçerli niteliksel betimlemelere, yapısal örüntüleri anlamaya, değişimi ve geri plandaki sosyal süreçleri keşfetmeye yöneldim. Bu çerçevede birkaç yönden ilişkisel-eleştirel sosyolojiden etkilendim (Danermark vd. 2003/2018; Donati ve Archer 2015; Kasapoğlu 2016; Restivo ve Loughlin 1987/2010). Şöyle ki; pozitivizmin formel ve okura mesafeli yaklaşımını benimsemedim; "çevre"deki insanların ve metinlerin sesini önemsedim; ikili mantıktan (kadın/erkek, yapı/eylem, kurban/fail vb.) kaçındım; uygulamalı sosyolojinin içinde yer alan özgül bir sorunu (depreme hazırlıksızlıktaki süreğenliği) anlamaya yönelen bir analiz yaptım; bir çekirdek kavrama (dirayetli toplum) dayanarak örüntüleri anlayıp açıklamaya çabaladım. Bu kavramı Balamir'den (2000) aldım, ama kavrama, toplumun tabandan kapsayıcı-eşitlikçi bir hedefle örgütlenerek kendini depreme dayanıkıılık ${ }^{2}$ yönünde dönüştürmesi gibi bir boyut ekledim veya kavramda var olan bu boyutu vurguladım (Açıkalın 2017a: 25). Örüntü bulma, anlama ve açıklama çabalarımın başlangıç düzeyinde olduğunun farkındayım, fakat üzerinde düşünmeye ve tartışmaya değecek kalitede olduğunu umuyorum. Çabamı değerli kılan öncelikle, hepimizin hayatını ilgilendirdiği halde sosyal bilimler topluluğu olarak hakkıyla ilgilenmediğimiz bir kamusal soruna dikkat çekmemdir.

Depremin sosyal boyutlarıyla ilgilenenlere bilimsel veya uygulama desteği (rehberliği) veren kurumların yokluğunda, konuya depremlerin hemen sonrasında artan geçici ilgimizin ve her kaliteden metni yayınlayan bazı "hakemli" mecraların varlığında, depreme karşı neden "önlem almamakta direnen" bir toplum olduğumuzu anlayamıyoruz. İşe yarayacak türde bir "iletişim" için, bilim topluluğunun kendi içinde ve sivil toplumun ilgili unsurlarıyla kurumsal/kolektif düzeyde ve sistemli şekilde yürüttüğü ilişkilerine dayanmak gerekiyor

\footnotetext{
${ }^{2}$ Dirençlilik kavramının deprem/afet yazınındaki kullanımını tanıtan iki metin olarak Kundak 2017 ile Varol ve Buluş Kırıkkaya 2017 gözden geçirilebilir.
} 
(Açıkalın 2017b). Bu kurumsal çerçeveyi bilimciler için sağlayan, bir "paradigma" olmasa bile (olması gerekmez ama), "paradigmamsı" yapılanmalardır. Paradigma, topluluğun, hakkında dertleneceği sorunsalları kurgulayan, çözüm yolları ve araçlarını sunan, tüm sürecin işleyişini düzenleyen kabulleri, kuralları ve normları kuran bir yapılanma olarak düşünülebilir. Aşağıda, buna benzer bir çerçevenin eksikliğinde, nasıl bir dağılmışılı, yetersizlik ve birbirini tanımama ortaya çıktığına işaret edeceğim.

Bilim dediğimiz alanda "olgu"lar hakkında kanı oluştururken, "kanıt" veya "veri" ile oldukça özgül ve sistemli bir ilişkiye gireriz. Bu durum, bilim alanını diğer bilgi alanlarından daha ayrıcalıklı bir konuma yerleştirmez. Olgunun, kanıtın veya verinin somutluğunu, gerçekliğini ve insan eliyle kurulmuşluğunu tartışmayı sürdürürüz (Fuller 1991; Danermark vd. 2003/2018). Ama bilim alanında kaldığımız sürece, kanılarımızı oluştururken kanıtlara başvurmayı önemseyip, bu kanıtları öyle ya da böyle, bilimcilerin anlayabileceği bir sistematik içinde kurmak (seçmek-toplamak, işlemek, çözümlemek, yorumlamak) ve sunmakla uğraştığımız müddetçe bir bilim topluluğu içinde olduğumuz söylenebilir. Topluluk, dil ve iletişim birbirini gerektirir; tüm bunlar aynı zamanda kural, norm ve gelenek demektir. Paradigmanın bu kavşakta sınırlayıcı, zorlayıcı, yani iktidarla ilgili yanları vardır. Fakat "iktidar" hakkında dertlenebilmek için onun var olması, bir "düzen" kurmuş olması gerekir. Deprem çalışmaları alanında (henüz) böyle bir yapılanma olmadığı kanısındayım; "olanı" bu makalede betimlemeyi deneyeceğim.

$\mathrm{Bu}$ doğrultuda "deprem çalışmaları" alanında, içerdiği kaynak sayısı ve alan çeşitliliği bakımından kapsamlı bir derlemeye (sözünü ettiğim veri tabanına -Açıkalın 2017a) dayanarak yazının temel özelliklerini, çoğu bilimci olan bir grup yazarın olgu/kanıt/veriyi nasıl kurup kullandığını irdeleyeceğim. Yazındaki bazı önemli (büyük kısmı metotla ilintili) sorunları daha kolay gösterebilmek için çok basit düzeyde bir sayısal analize de başvuracağım. Böylece depremle ilgili sosyal bilginin daha kaliteli ve etkin şekilde oluşturulması için çağrıda bulunmayı, bu yönde birkaç öneri geliştirerek, "paradigmamsı" bir yapılanmanın (veya bilimsel söylemin) gerekliliğini tartışmaya açmayı hedefliyorum.

Kullandığım veri tabanındaki kaynakları seçme sürecini tanıtmakla işe başlayacağım. Bu sayede hem benim izlediğim, hem de yazında izlenen "iş yapma yolları, araçları ve tekniklerinin bütünü" anlamında metot hakkında bilgi sunacağım. Bunun bir parçası olarak bu makalede kaynakları sınıflamada kullandığım ölçütleri geliştirme sürecini anlatacağım. Ardından, veri tabanında yer alan kaynaklardaki kanıtların/verilerin türlerini, analizlerde kapsanan zaman dilimi ve mekânı değerlendireceğim. Bundan sonra yazarları destekleyen kurumlar ve ağlar ile yazarların etkileşimlerine ışık tutacağım. Son olarak, tüm bulgularıma dayanarak bazı çıkarımlarda bulunup, araştırmalar için birkaç öneri sunacağım.

\section{Kaynakları Seçme Süreci}

Kullandığım veri tabanı Türkiye'deki deprem deneyiminin sosyal boyutlarıyla ilgili 2000'den 2016 sonuna kadar yazılmış yüzü aşkın metinden oluşuyordu. Bilimsel, yönetsel ve popüler veri tabanlarımız gelişmeye başladı (ör., ODTÜ Afet Yönetim Merkezi'nce geliştirilip AFAD'a devredilen Veri Tabanı). Fakat kaynaklar hâlâ dağınık olduğundan, metinlere erişim ve sistematik tarama güçlükleri sürüyor. Bu nedenle zamanında göremediğim veya erişemediğim için analize katamadığım bazı önemli metinler oldu. Ayrıca metinler arasında amaçsal bir seçim yaptım: Yazın büyük ölçüde 1999'daki Marmara depremlerinin ardından geliştiğinden, metinleri seçmek için yaptığım taramada 2000 yılını başlangıç kabul ettim. Ulakbim, Google Akademik, ebscohost ve kütüphane veri tabanları ile eserlerin kaynakçalarını taradım. Yayınlanmamış yüksek lisans ve doktora tezleri ile araştırma raporlarını, zaman ve emek kısıtları yüzünden büyük ölçüde kapsama almadım. Akademik metinlere ağırlık vermekle birlikte, bazı raporları, popüler metinleri ve çoğu Van'a ilişkin olan haberleri, yazındaki kimi önemli boşlukları doldurabilmek için kullandım.

Bu çerçevede kaynak seçerken üç ölçüt kullandım. Birincisi, mimari, şehir-bölge planlama ve yönetim konularında sosyal bilgi içeren bazı örnekler ile sosyal bilgiyi dolaylı olarak ürettiğim 
bazı jeoloji metinlerini, veri tabanlarını, proje ve programların kavramsal tanıtımlarını kapsama aldım. "Sosyal olmayan alan"lardaki bu kaynakları, özgül konularda işime yararlılıklarına göre seçtim ve olabildiğince az örnekle yetindim. İkincisi, veri tabanında sosyoloji metinlerine öncelik verdim; küçük ve rassal olmayan örneklemlere dayalı psikoloji ve eğitim metinlerinden az sayıda örneği kapsayıcılığı, özgünlüğü ve ilgili oluşuna göre seçtim. Son olarak, "kabul edilebilirlik eşiğini" çok altta tutmakla birlikte, bir "kalite elemesi" yaptım -bu amaçla kullandığım birkaç basit ölçütü aşağıda aktardım. Kalite sorunlarından dolayı elediğim metinlerin yararı, onlar sayesinde yazındaki sistematik sorunlar üzerine düşünmem oldu ve ortaya bu makale çıktı.

Oluşturduğum bu veri tabanına dayalı analizler istatistiksel bakımdan bir genellemeye uygun değil. 2017 yılı itibariyle depremle ilgilenenlerin çalışmalarından oluşan kolektif ürünün ideal anlamda temsilini yarattığımı da iddia edemem. Buna rağmen bu veri tabanı ve onu aşağıdaki gibi tanıtıp, eleştirel yönden değerlendirmem bir işe yarayabilir: Bu sayede ilk kez depremin sosyal boyutuna ilişkin kapsamlı bir bütünlük üzerine tartışabilecek durumdayız.

\subsection{Sınıflamada İki Güçlük}

Bu makalede yer alan basit analizler için basit sınıflamalar yaptım. Sınıflamalarımı bu makale açısından ilginç kılan öncelikle, veri tabanındaki metinleri sınıflarken yaşadığım iki yönlü güçlüktü. Bunlardan ilkini, metinleri, yazarın bildirdiği veya benim belirlediğim metotla ilgili ölçütlere göre sınıflamada yaşadım. Örneğin bazı metinler, bilimsel bir araştırmayı yansıttığını iddia ediyor, bir bilimsel dergide yayınlanmış veya bu tür bir konferansta sunulmuştu, ama araştırma prosedürünü tanıtmamış veya izleyeceğini bildirdiği prosedürü izlememişti. Burada en genel anlamıyla pozitivizmin kurallarına uymayanlardan söz ettiğim sanılmasın; sunulan bilginin "değeri" hakkında ana hatlarıyla bir fikir geliştirebilmeye yarayacak çok temel düzeyde bilgilendirmeleri kast ediyorum. Örneğin, araştırmanın nerede ve ne zaman yapıldığını, kanıtların hangi kaynaklardan derlendiğini, nasıl bir iddianın (argüman) peşinde olunduğunu birer cümleyle bildirmeyi; depremden etkilenme düzeyini sorgularken deprem deneyimi yaşayanlara odaklanmayı, topladığı verileri az da olsa işlemiş olmayı, sayısal analizde çok fazla "cevapsız" çıkınca bunu bildirip yorumlamayı, bulgular arasındaki tutarlıı̆ga dikkat etmeyi veya bariz bir geçerlilik sorununa (ör., Van'ın toplamında 644 ölüm olmuştu ama kent merkezindeki bir ankette katılımcıların \%20'sinin yakınını kaybettiği kaydedilmişti) rağmen örneklemin genellenebilir olduğunu iddia etmemeyi vb. kast ediyorum. Bu tür örneklerin karşısında, bilimsel prosedürleri izleme yönünde bir iddiası veya kaygısı olmadığı halde, sorunlu "bilimsel" çalışmalardan daha güvenilir veri-bulgu, dikkate değer analiz ve yorum sunan haber, anı-tanıklık, rapor ve değerlendirmeler vardı.

Sınıflamada zorluk yaratan ikinci konu deprem üzerine çalışmanın doğasıyla ilgiliydi. Depremin sosyal boyutlarına ilişkin çalışmalar, hangi düşünümsellik düzeyini taşırsa taşısınlar, araçsal bilgiyle (uygulamalı sosyal bilim alanıyla) az ya da çok temas içinde olurlar: Depremzedeler yaralarını sarabilmişler mi, onlara kimler yardım etmiş, kim etmemiş, neden etmiş veya etmemiş, kimin neye ihtiyacı varmış, neden o bir ihtiyaçmış, bir daha deprem olsa korunabilecekler miymiş, neden, nasıl... Bir konunun "acil" ve "yakıcı" bir yanı varsa, politik bir yanı vardır; politikanın da bir örgütlenmesi, kültürü ve ekonomisi vardır. Bu nedenle deprem çalışmaları alanında "bilimsel" olanların ötesinde, çok çeşitli çalışmalara gerek duyulur. Sadece anlamak-anlamlandırmak için bile, her türlü gözlem, görüşme, anı, anlatı, haber, belge, istatistik, değerlendirme ve yorum önemlidir. Dolayısıyla veriyi toplama, işleme, sunma ve kullanma tarzı, tekniği veya amacı bakımından belirleyebileceğimiz çeşitli türler arasında "melezlenmeler" (ilişkisellik) sıklıkla başvurulan, hatta başvurulması gereken bir özellik haline gelir. O kadar ki, metot özellikleri bakımından oldukça sorunlu bir metni, inmal edilmiş bir konunun varlığına işaret etmesi önemli kılar. Bu anlamda "melezlik", kalite bakımından "ikircikli" (içinde zıt özellikler barındırdığından kategorize edilmesi güç olan) bir duruma da karşılık gelebilir: Örneğin, çalışmanın konusu, yeri, dönemi, teknikleri veya sonuçları gibi ölçütlerden en az biri bakımından önemli olan bir metin, diğer ölçütler bakımından sorunlu olabilir. 
Sonuçta ölçüt geliştirme ve sistemli şekilde uygulama güçlüklerine yol açan iki faktöre dikkat çekiyorum: "kalite" ve "işin doğası". Bu iki faktör arasında da etkileşimler oluştukça çeşitlenmeler (ilişkisellik, melezlik, ikircikler) artıyor, sınıflamalar güçleşiyor. Bu güçlükleri aşabilmek için, aşağıdaki başlıklara ve tablolara yansıyan şekilde, durumu özetleme kabiliyeti yüksek ama çok basit ölçütler geliştirdim.

\section{Kaynak Sayısı, Veri Türü, Amaç Ve Teorinin Yokluğu}

Çeşitli çalışmalarımda haberleri ve jeoloji metinlerini dışarıda tutup, bir dizi faaliyet raporunu da tek bir metin gibi sayarak, analizin yaklaşık 150 kaynağa dayandığını belirtmiştim (Açıkalın 2017a, b, c, 2018). Bu makalede, Tablo 1'deki ilk iki kategoride yer alan 139 kaynağı kullanacağım. ${ }^{3}$ Tablo 1 , her kaynağa uygulayabileceğim "esnek" bir ölçüte göre ("veri-kanıt" toplama/kullanma biçimi) veri tabanını dört kategoriye ayırıyor.

Tablo 1: Veri tabanındaki kaynaklar

\begin{tabular}{|l|r|r|}
\hline Kaynaklar & $\begin{array}{r}\text { Metin } \\
\text { Sayısı }\end{array}$ & $\%$ \\
\hline Araştırma, rapor, tanıklık -veri göreli sistemli toplanmış & 115 & 64 \\
\hline Inceleme, değerlendirme -veri göreli serbest seçilmiş & 24 & 13 \\
\hline $\begin{array}{l}\text { Diğerleri: eğitim materyali, proje-program tanıtımı, veri tabanı, } \\
\text { söyleşi, anma }\end{array}$ & 11 & 6 \\
\hline Haberler & 30 & 17 \\
\hline TOPLAM & $\mathbf{1 8 0}$ & $\mathbf{1 0 0}$ \\
\hline
\end{tabular}

Veri tabanının \%64'ünü az çok sistemli şekilde toplanmış, işlenmiş ve sunulmuş verilere dayanan araştırma, tanıklık ve raporlar oluşturuyor. İnceleme ve değerlendirme olarak adlandırdığım metinleri ayrı bir kümede topladım, çünkü buradaki tanıtım veya tartışmalarda uygun veri göreli daha serbest bir tarzda seçilmiş4. Veri tabanında \%13 ile temsil edilen bu kümede, afet yönetimine ilişkin durum tespitleri ve yorumlar yer alıyor. Bu iki kategori metinlerin değeri hakkında imada bulunmuyor; örneğin araştırmalar incelemelerden daha kaliteli veya önemli anlamına gelmiyor. Her kategoride yazına önemli katkı sunan veya kalitesi tartışmalı metinler var. "Diğerleri" kümesi (\%6) daha çok analize girdi veren veri setleri (ör., AFAD, TUIK istatistikleri) veya eğitim materyali gibi kaynakları içeriyor. Haberleri ise, kaynakların beşte birine yakınını oluşturduğundan ayrı bir küme olarak belirledim. Haberlerin büyük kısmı 2011'deki Van depremleriyle ilgili. Van hakkındaki haber dışı metinlerin sayısı az olduğundan, Van'daki durumu ve karşılaştırma yaparak değişimleri anlamak güçtü; haberler bu güçlüğü kısmen aşmama yardımcı oldu. Bu durum ne kadar çok ve kaliteli araştırma gerektiğine işaret ediyor.

Bir fikir vermek amacıyla Tablo 2'de yalnız göreli sistemli toplanmış verilere dayanan metinleri, ilk elden toplanmış "ampirik" ve başkasının topladıklarına dayalı "hazır veri" türlerine göre sınıfladım. Veri tabanında ampirik veri içeren metinler ağırlıkta (\%78).

Tablo 2: "Sistemli" Toplanmış Verilerin Türü

\begin{tabular}{|l|r|r|}
\hline Tür & Sayı & $\%$ \\
\hline Ampirik & 90 & 78 \\
\hline Hazır & 25 & 22 \\
\hline TOPLAM & 115 & $\mathbf{1 0 0}$ \\
\hline
\end{tabular}

\footnotetext{
${ }^{3}$ Bu makaleye, kitabımda yer alan üç “tekrar metni”ni katmadım. Bunlarda, belli bir veri seti ve analiz orijinal metinden önemli bir içerik farkı olmadan kullanılmıştı. Bunların yerine, 2017 yılında yayınlanan kitabımdaki üç araştırmayı kullandım. Bunlar, ampirik veriye dayalı iki Van analizi ve hazır veriye dayalı bir Türkiye analizidir.

4 "Göreli serbest" seçimle, daha çok bir tartışmayı destekleyecek kanıtlar bulmaya odaklanmayı kast ediyorum.
} 
$\mathrm{Bu}$ sonucu yorumlamadan önce yine kalite ve işin doğası nedenleriyle oluşan sınıflama güçlüklerini kaydetmek istiyorum. "Hazır veri analizi" yaptığını belirtenler arasında, alındığı kaynaktaki verileri aynen veya özetleyerek aktaranlar vardı; bunları hazır veri analizi olarak kodlamadım. Bu kategoride yalnız verileri sistematik şekilde yeni bir işlemden geçirip bir "bulgu" üretenleri dikkate aldım. Ampirik ve hazır veri kaynaklarının ikisini de kullandığını belirten veya böyle bir izlenim veren de dokuz metin vardı (\%8). Ancak bunların altısında iki veri türünden biri neredeyse hiç kullanılmamıştı veya kullanımı çok sorunluydu. Örneğin, birinde içerik analizi, diğerinde derinlemesine görüşme kullanıldığı bildirilmişti, fakat bunlara ilişkin ne toplam veri kaynağı veya katılımcı sayısı, ne de ilgili teknikle toplanan verilerden edinilen genel veya özgül sonuçlar sistemli şekilde veriliyordu. Birinde bir gazeteden iki alıntı (yukarıda "serbest veri seçimi" olarak tarif ettiğim türde kullanımlar); diğerinde görüşmelerden edinildiği söylenen ama kanıtı sunulmamış genel malumat metnin birkaç yerinde aktarılmıştı. Bu gibi sorunlar yüzünden, sınıflamada basitlik ilkesine uyup, iki veri türünü hakkıyla kullanan üç metin de dâhil hepsini ya baskın özelliğine göre ampirik veya hazır veri türünden birinde veya inceleme kategorisinde sınıfladım.

Tablo 1 ve 2'deki dağılımlar amaçsal seçimimden etkilenmesine rağmen yazındaki bazı örüntüler hakkında ipuçları veriyor. Öncelikle araştırmalara ve ampirik veriye duyulan ilgi, deprem gibi kriz yaratan olayların toplumsal etkilerini somut kanıtlara dayanarak bilmebildirme isteğini yansıtıyor. Fakat hazır verinin metinlerin neredeyse beşte birinde kullanılmış olması, kısmen bu tür veri kaynaklarının yetersizliğine, kısmen hazır veriye erişim güçlüklerine ve kısmen de hazır veriye dayalı analiz yapma kapasitesindeki sınırlılıklara işaret ediyor olabilir.

Bu başı ık altında son olarak şu noktayı vurgulamak isterim: Veri tabanında yer alan 139 metindeki amaç daha çok var olan durumu ortaya koymak, yani betimleme yapmaktı. Betimlemeler şüphesiz özgün teorileri besler; bu noktada bir sorun görmüyorum. Buna rağmen, betimlemenin nasıl bir düşünsel temele veya yol haritasına dayanarak yapıldığına duyulan sınırlı ilgiyi sorunlu buluyorum. Yayınlandıkları veya sunuldukları mecralara veya yazarların ifadelerine göre bilimsel olma amacı/iddiası taşıyan metinlerden bir teoriye dayanan veya bulgularını teori ışığında/teorik düzeyde tartışan; teorik çıkarımlar, modeller sunan, kavramlar öneren kaynaklar epey az. Bu eksiklik sorunlarımızı (ve aslında kendimizi) anlama ve açıklama olanaklarımızı kısıtlıyor.

\section{Zamanla İlgili Özellikler}

Veri tabanındaki metinlerin zamanla ilgili özelliklerini, analizlerin odaklandıkları döneme ve yayınlandıkları tarihe göre irdeledim. Deprem sonrası dönemlerin tanımını yazından yararlanarak şöyle yaptım (Açıkalın 2017a): İlk bir kaç hafta depremzede açısından akut dönem, destek verenler açısından acil yardım dönemidir. Bir yıl boyunca oluşan gelişmeler iyileş(tir)me ve sonraki yıllar yeniden yapılan(dır)ma dönemleridir. Depreme hazırlığın her döneme yayılması gerekir, fakat bu alandaki etkinlikler yazında diğer dönemlerden ayrıştırılarak sınıflanmaktadır; ben de burada aynı yaklaşımı benimsedim.

Metinlerde birden fazla dönem hakkında bilgi verilebilmektedir. Tablo 3'te 139 metindeki dönemlerin çalışılma sıklığını gösterdim; oransal dağılımları "kayıt" toplamı olan 212 üzerinden hesapladım. 
Tablo 3: Deprem sonrasında hakkında bilgi üretilen dönemler

\begin{tabular}{|l|r|r|}
\hline Dönem & $\begin{array}{r}\text { Dönemin } \\
\text { çalışılma } \\
\text { sıklığı }\end{array}$ & $\%$ \\
\hline 1: Akut dönem /acil yardım & 41 & 19 \\
\hline 2: İyileş(tir)me & 81 & 38 \\
\hline 3: Yeniden yapılan(dır)ma & 50 & 24 \\
\hline 4: Depreme hazırlık & 40 & 19 \\
\hline TOPLAM KAYIT & $\mathbf{2 1 2}$ & 100 \\
\hline TOPLAM METIN & $\mathbf{( 1 3 9 )}$ & \\
\hline
\end{tabular}

Tablo 3'e göre veri tabanında iyileşme dönemi (\%38), akut dönem ve hazırlık döneminin (\%19'ar) toplamı kadar yer tutuyor. Şüphesiz bu dağılım benim amaçsal seçimimden etkilenmiş durumda, ama seçimde kota uygulamadığımdan (yani hangi dönem ne ölçüde temsil edilsin diye bir eşik belirlemediğimden), yazının bütünü hakkında bir fikir veriyor. Ortaya çıkan dağılım dolaylı olarak, durum veya intiyaç saptamak (alan çalışmaları) veya uygulamalara destek olmak için en çok, kriz anı yatıştıktan sonraki bir yılın (iyileşme döneminin) kullanıldığı izlenimini veriyor.

Zamanla ilgili ikinci konu, deprem dönemleri bakımından analizlerin kesitsel mi (tek dönem), yoksa zaman boyutlu mu (birden fazla dönem) yapıldıklarıdır. ${ }^{5}$

Tablo 4: Kaynaklarda kapsanan dönem sayısı

\begin{tabular}{|l|r|r|}
\hline Dönem & $\begin{array}{r}\text { Metin } \\
\text { sayısı }\end{array}$ & $\%$ \\
\hline Yalnız bir dönem (kesitsel) & 82 & 59 \\
\hline Birden fazla dönem (zaman boyutlu) & 57 & 41 \\
\hline TOPLAM & 139 & 100 \\
\hline
\end{tabular}

Yalnız bir döneme (çoğunlukla o dönemdeki bir ana) odaklanan çalışmalar 139 metnin \%59'unu oluşturuyor (Tablo 4). Birden fazla dönem hakkında bilgi içerdiğini kaydettiğim 57 metin (\%41) bulunmakla birlikte, bu kaynaklara dayanarak dönemler arasında anlamlı ilişkiler kurmak ve süreçteki değişimleri saptamak pek kolay değil (Açıkalın 2017a).

Tablo 5, kesitsel analizde metinlerin odaklandıkları dönemlerin dağılımını gösteriyor. Buna göre, kesitsel analiz yapan 82 metinde en fazla depreme hazırlık dönemi işlenmiş (\%39); bunu iyileşme dönemi izliyor (\%32).

Tablo 5: Kesitsel analizlerdeki dönemler

\begin{tabular}{|l|r|r|}
\hline Dönem & $\begin{array}{r}\text { Metin } \\
\text { sayısı }\end{array}$ & $\%$ \\
\hline 1: akut/acil yardım & 7 & 9 \\
\hline 2: iyileş(tir)me & 26 & 32 \\
\hline 3: yeniden yapılan(dır)ma & 17 & 21 \\
\hline 4: depreme hazırlık & 32 & 39 \\
\hline TOPLAM & $\mathbf{8 2}$ & $\mathbf{1 0 0}$ \\
\hline
\end{tabular}

\footnotetext{
${ }^{5}$ Zaman boyutlu analizi "süreçteki değişmelerin gözlemlenmesi" yerine, "birden fazla dönemin içerilmesi" olarak tanımladım. Bu tanımda kavramsal bir sorun olmasına rağmen, gerçek anlamda süreç analizinin azlığından dolayı bu pragmatik sınıflamayı tercih ettim.
} 
Kesitsel analizde hazırlık döneminin daha görünür olması (Tablo 5), bu dönemin diğer dönemlerden yalıtılmış olarak ele alınmasıyla ilgili ve (belki de kısmen bu nedenle) yazının bütününde daha sınırlı ölçüde vurgulanmış (212 kaydın \%19'u -Tablo 3).

Benzeri bir durum diğer dönemler için geçerli değil. Şöyle ki, akut dönem hazırlık döneminin tersine kesitsel analizde büyük ölçüde eriyor: 82 metnin yalnız \%9'u bu döneme ilişkin (Tablo 5). Oysa zaman boyutlu analizi ortaya koyan Tablo 6'da 57 metnin \%60'ı akut dönemi içeriyor. O halde, Tablo 3'te 212 kayıttan \%19'unun akut dönem hakkında olmasını nasıl yorumlamalı? Bunun nedeni, araştırmacıların ilgisinin ilk iki döneme birden yönelmesi olabilir ve muhtemelen bu yönelimi, ilk dönemin ikincinin bir parçası olarak algılanması beslemiştir. Aslında iyileşme ve yeniden yapılanma dönemleri de birlikte ele alınma eğiliminde: Tablo 6 metinlerin üçte ikisinde birbirini izleyen ikişer dönem içerildiğini gösteriyor.

Tablo 6: Zaman boyutlu analizlerdeki dönemler

\begin{tabular}{|l|r|r|}
\hline Dönemler & $\begin{array}{r}\text { Metin } \\
\text { sayıs }\end{array}$ & $\%$ \\
\hline 1 ve 2 & 21 & \\
\hline 2 ve 3 & 20 & \\
\hline Diğer & 2 & \\
\hline Toplam - İki dönem & 43 & 75 \\
\hline 1,2 ve 3 & 8 & \\
\hline $1,2,3$ ve 4 & 6 & \\
\hline Toplam - Üç veya dört dönem & 14 & 25 \\
\hline GENEL TOPLAM & 57 & 100 \\
\hline
\end{tabular}

Bir ve ikinci veya iki ve üçüncü dönemlerin birlikte çalışılması, dönemler arasındaki geçişliliğe dikkat edilip, bütünlüklü bir yaklaşım kullanıldığı ölçüde olumludur. Ancak metinlerin içeriği daha çok iyileşme döneminin merkeze konduğu, akut dönemin veya yeniden yapılanmanın özgün yanlarının daha az dikkat çektiği izlenimini vermektedir (Açıkalın 2017a). Ayrıca Tablo 6 , üç veya dört dönemi birlikte çalışan kaynakların azınlıkta olduğuna da işaret ediyor. $\mathrm{Bu}$ durumun ortaya çıkışında, ilgi, bilgi ve ilişkisel bakış açısının eksikliğinin etkisi olabilir.

Zamanla ilgili üçüncü konu, kaynakların yayınlandıkları yılla ilgili. Tablo 7'ye göre kaynakların \%39'u 1999 Marmara depremlerini izleyen ilk beş yılda yazılmış; üstelik en fazla ayıklamayı bu döneme ait metinlerde yaptım. Sonraki beş yıllık döneme (2006-2011) ait çalışmalar veri tabanının \%26'sını ve üçüncü dönemdekiler (2012-2017) \%35'ini oluşturuyor. Üçüncü dönem için taramada bulduğum neredeyse tüm metinleri kullandığım halde Marmara-sonrası dönemdeki sayıya ulaşamadım. Buna rağmen Tablo 7, 2011'in sonunda oluşan Van depremlerinin, konu hakkındaki bilgi üretimini canlandırdığı izlenimini veriyor.

Tablo 7: Metinlerin Yayın Yılı

\begin{tabular}{|l|r|r|}
\hline Yıl & $\begin{array}{r}\text { Metin } \\
\text { Sayısı }\end{array}$ & \\
\hline $2000-2005$ & 54 & 39 \\
\hline $2006-2011$ & 36 & 26 \\
\hline $2012-2017$ & 49 & 35 \\
\hline TOPLAM & 139 & 100 \\
\hline
\end{tabular}




\section{Mekânla İlgili Özellikler}

Mekân çeşitliliğine özen göstermeme rağmen veri tabanındaki metinlerin \%72'sinin Marmara ve Doğu bölgeleri üzerine olması (Tablo 8), depremin sosyal boyutlarına ilişkin çalışmaların daha çok kriz dönemlerinde canlandığı izlenimini destekliyor.

Tablo 8'e göre Marmara hakkındaki 60 metnin yaklaşık beşte biri bölgenin geneline, bir o kadarı Düzce'ye, kalanı da depremden etkilenen diğer il ve ilçe merkezlerine ilişkin. Doğu'daki yerler hakkında yazılan metinlerin dörtte üçü Van'a, diğerleri Bingöl, Erzurum, Elazığ ve Tunceli'ye ait. Marmara ve Doğu bölgelerini konu alan 100 metin içinde yalnız beşi köylerle ilgili. Oysa örneğin Van'da 40 köyün "haritadan silindiği" kayıtlara geçmişti (AFADVan Valiliği 2012: 9). Yakın dönemlerde yıkıcı bir sarsıntı yaşamamış olan Ege ile orta ölçekli sarsıntılar yaşayan İç ve Güney Anadolu'yu konu alan da yalnız sekiz metin var (\%5). Fakat bu metinlerin çoğunun içeriği, başlıklarından izlenebileceği üzere (Açıkalın 2017a: Kaynakça), konuları bakımından mekânları karşılaştırmaya uygun değil. Ege'de İzmir, İç Anadolu'da Afyon-Dinar, Çankırı ve Eskişehir ile Güney'de Adana veri tabanında temsil edilmiş. Bu bölgelerde 1999 sonrasında sarsıcı bir deprem (kriz) yaşanmamış olması ve bu bölgelerin nüfus büyüklüğü ve ekonomik önemi bakımından mekân hiyerarşisinin alt katmanında bulunmaları (konum), onların sosyal bilimlerde deprem çalışmaları kapsamına alınmamalarına yol açmış görünüyor.

Tablo 8: Çalışmaların Mekânı (2000-2017)

\begin{tabular}{|l|r|r|}
\hline BÖLGE & $\begin{array}{r}\text { Metin } \\
\text { Sayısı }\end{array}$ & \multicolumn{1}{|c|}{$\%$} \\
\hline Marmara & 12 & \\
\hline Genel & 14 & \\
\hline Düzce & 34 & \\
\hline Diğer & 60 & 43 \\
\hline Marmara Toplam & & \\
\hline Doğu & 34 & \\
\hline Van & 6 & \\
\hline Diğer & 40 & 29 \\
\hline Doğu Toplam & 8 & 5 \\
\hline Ege, İç ve Güney Anadolu & 9 & 6 \\
\hline Türkiye -il/bölge belirlenmiş & 24 & 17 \\
\hline Genel -kapsam belirsiz & 139 & 100 \\
\hline TOPLAM & & \\
\hline
\end{tabular}

Mekânları rassal veya amaçsal olarak ama dikkatlice seçip bir Türkiye temsili yaratan kaynaklar yalnız dokuz tane (\%6) (Tablo 8). Oysa Türkiye veya herhangi bir deprem mekânı hakkında "genelde" söz söyleyen 24 metin var (\%17). Teorik birkaç metin dışında, "genel" kategorisindekilerin çoğunu "inceleme" başlığı altında kodladıklarım oluşturuyor. Bunlar, farklı deprem dönemlerinde, genelde deprem bölgeleri veya özelde Türkiye'deki deprem yönetimi, ilgili mevzuat, barınma veya psiko-sosyal destek gibi konularda yapılması gerekenleri tanıtıyorlar veya yapılanları tartışıyorlar.

Yukarıda sarsıcı depremleri izleyen beş yıllık dönemlerde bu bölgelere ilişkin bilgi üretiminin arttığını kaydetmiştim. Peki, bu dönemlerin etkisiyle artan bir farkındalıkla farklı risk alanlarına da ilgi artıyor mu? Örneğin 2000-05 ve 2012-17 dönemlerinin arasında kalan (Van depremlerine kadar geçen) dönemde ne değişmiş? Eğer 2006'dan 2011'in Kasımına kadar 
yayınlanmış metinlerde mekânsal çeşitlenme gözleniyorsa, bilgi üretenlerin ilgisinde sistematik ve stratejik gelişmeler olduğu düşünülebilir.

Tablo 9: Ara Dönemdeki Çalışmalarda Mekân (2006-2011)*

\begin{tabular}{|c|c|c|c|c|}
\hline \multirow[t]{2}{*}{ YER } & \multicolumn{4}{|c|}{ Metinler } \\
\hline & 2006-07 & 2008-09 & 2010-11 & Toplam \\
\hline Genel -kapsam tanımlanmamış & $\% 21(5)$ & $\% 56(5)$ & $\% 25(2)$ & $\% 29(12)$ \\
\hline Türkiye -kapsam tanımlanmış & $\% 4 \quad(1)$ & & & $\% 2 \quad(1)$ \\
\hline Marmara & $\% 58(14)$ & $\% 44(4)$ & $\% 50(4)$ & $\% 54(22)$ \\
\hline Doğu (Erzurum, Elazığ, Tunceli) & $\% 13$ (3) & & $\% 13(1)$ & $\% 10 \quad(4)$ \\
\hline İç (Eskişehir, Afyon-Dinar, Çankırı) & $\% 4 \quad(1)$ & & $\% 12(1)$ & $\% 5 \quad(2)$ \\
\hline TOPLAM & $\% 100(24)$ & $\% 100(9)$ & $\% 100(8)$ & $\% 100(41)$ \\
\hline
\end{tabular}

Tablo 9, 2006'dan Ekim 2011 sonunda Van'daki ilk depreme kadar geçen ara dönemde konuya ilginin giderek azaldığına işaret ediyor: 2006-07'de 24 metin varken, izleyen dönemlerde metin sayısı bunun yarısına bile ulaşmıyor.

Ayrıca ara dönemde (2006-11) Türkiye'den veya depremden genel anlamda söz eden kaynaklar \%29 iken (Tablo 9); 17 yılın bütününde \%17 (Tablo 8). Ara dönemde en fazla \%55 ile Marmara çalışıımışken (Tablo 9); 17 yılda Marmara çalışmalarının ortalaması \%43 (Tablo 8). Ara dönemde yükselip 17 yıllık ortalamada göreli düşük olan "genel" ve Marmara ilgisi, Van üzerine yazılan yazılarla ilgili görünüyor: Veri tabanında 2011 tarihli 12 metinden yalnız dördü ilk 10 aya ait ve Van hakkındaki 34 metnin hepsi deprem sonrasında yazılmış (Açıkalın 2017a: Kaynakça). Yani Van, deprem konusuna ilginin yeniden artmasına yol açmış.

Tablo 9 ara dönemde cılız da olsa bir mekânsal çeşitlenme eğiliminin başladığına işaret ediyor: Kapsamı belirli bir Türkiye çalışması ile Doğu ve İç Anadolu'dan yerel örnekler 41 metnin \%17'sini oluşturuyor. Ne var ki veri tabanında bu eğilimin izleri Van depremleri sonrasında gözlenemiyor. Ayrıca Van depremlerinin ardından genelde depreme yeniden yönelen ilgi de Marmara depremleri sonrasındaki düzeye çıkmıyor.

Yukarıda kaydettiğim bağlamla ilgili iki faktörün (kriz ve konum) bu bulguyu yorumlamada da geçerli olması muhtemeldir. Bunun yanı sıra yazında bağlamla ilgili olarak sosyal bilimcilerin zaten dağınık olan ilgilerini iyice zayıflatan üç faktör daha dikkat çekiyor. Bunlar, Marmara depremleri sonrasındaki sürecin demokratikleşme tartışmalarıyla ilişkilendirilmesi ile AFAD'ın artan yönetim ve eğitim kapasitesine, AFAD'ın ve belediyelerin gelişen teknolojik donanımlarına ve kentsel dönüşümün dayanıklılık kazanılmasındaki asıl mesele olduğuna ilişkin anlatımlardır (Açıkalın 2017a; Akşit vd. 2003; Altıntaş 2012; Köktürk ve Köktürk 2007; TSKB 2012).

Bireylerin eğitimi-krizin yönetimi, teknoloji ve kentsel dönüşüm üçlüsünün gerçekten dayanıkııık (depreme hazırlık) sağlayıp sağlamadığı yazında yeterince sorgulanmamıştır (Açıkalın 2017c, 2018). Örneğin, AFAD'ın birkaç saat bilgilendirme oturumlarına katılan bir milyon kişiden yüzde kaçı ilk 72 saate hazırdır, evlerinde çanta hazırlamıştır, dolapları duvara çakmıştır, bir mahalle örgütlenmesi oluşturmuş veya var olan örgütlenmeye katılmıştır? Bu ve benzeri konulardaki hazırlıklar yetersizse, sahip olunan teknolojik donanım yeterince etkin kullanılamayacaktır ve 10-20 katlı depreme dayanıklı binalar deprem sonrasında sağlam kalsa bile, binalardaki yangından yaşılırı tahliye etmekten, susuz veya elektriksiz ortamlarda yaşamaya kadar çeşitli sorunlarla başa çıkmak güç olmayı sürdürecektir (Açıkalın ve Çiftçi 2018). 


\section{Yazarları Destekleyen Kurumlar, Toplumsal Ağlar ve Etkileşimler}

Yazındaki yetersizlik, dağınıklık ve kalite sorunlarından bireyleri sorumlu tutmak kolay görünüyor; ama bunun fazla kolaycı bir yaklaşım olacağına ilişkin bazı ipuçları var (daha derin araştırmalarla bu kanıtları hem çoğaltmak hem de sorgulamak olanaklı). illk ipucunu metinleri yayınlayan kuruluşun türüne (yayıncının özel veya kamusal olması; resmi veya sivil kamuyu temsil etmesi) bakarak edinebiliriz, çünkü depremin sosyal boyutlarını önemseyenler araştırma sipariş eder, toplantılar düzenler ve çalışmaların kamuyla paylaşımına destek olurlar. İkinci ipucunu ise yazarların uzmanlık alanına-çalıştığı kuruluşa bakarak edinebiliriz, çünkü yazarın uzman kimliği konuyla ilgilenilen alanlara ilişkin dolaylı bir kanıt sunar.

Tablo 10: Metinlerin Yayıncıları *

\begin{tabular}{|c|c|c|}
\hline Yayıncı & $\begin{array}{l}\text { Metin } \\
\text { Sayısı }\end{array}$ & $\%$ \\
\hline Resmi Kamu (RTÜK, AFAD, Valilik, Kalk. Ajs., TÜBITAK, Belediye) & 8 & 7 \\
\hline \multicolumn{3}{|l|}{ Üniversite ve Resmi Kamu Ortaklığı } \\
\hline Üniversite yayınları & 37 & \\
\hline Üniversite-Kamu Ortaklığı & 12 & \\
\hline Üniversite ve üniversite-kamu ortaklığı Toplam & 49 & 40 \\
\hline \multicolumn{3}{|l|}{ Sivil Toplum (STK'lar, meslek örgütleri, sendikalar vb.) } \\
\hline Kendi ürünlerine/işlerine ait yayınlar & 25 & \\
\hline Düzenli hakemli dergilerindeki makaleler, seri numaralı kitaplar & 15 & \\
\hline Düzenledikleri toplantılardaki sunumlar, tartışmalar & 8 & \\
\hline Sivil Toplum Toplam & 48 & 40 \\
\hline Özel yayınevleri (akademik metinlerin yayınlandığı dergiler dâhil) & 16 & 13 \\
\hline TOPLAM & 121 & 100 \\
\hline
\end{tabular}

Tablo 10'u yorumlamadan önce, oluşturduğum veri tabanının sınırlılıklarını bir kez daha hatırlatmak isterim: Burada sunduğum temsilin geçerliliğini sorgulamak ve daha geçerli bir temsil çıkarılabilmek için üniversitelerin, TÜBiTAK'ın, AFAD'ın ve belediyelerin arşivlerinin, içerdikleri sosyal bilgi açısından büyük bir titizlikle taranması gerekiyor. Ortaya çıkması muhtemel bir temsil çarpıtmasından dolayı bulguları, en genel anlamda veri tabanında göreli olarak az ya da çok görünmeleri açısından değerlendiriyorum.

Tablo 10'daki dağılıma göre, metinlerin görünürlük kazanmasına en çok resmi veya sivil kamusal kimlikli kuruluşlar (\%87) katkıda bulunmuşlar; özel yayınevlerince basılan yazılar veri tabanının \%13'ünde kalmış. Özel yayınevleri, akademik yazıları yayınlayan hakemli dergileri de kapsamaktadır. Veri tabanına yansıdığı kadarıyla resmi kamunun (merkezi ve yerel yönetimler ile bilgi üretimiyle yakından ilgilenen TÜBITAK, AFAD gibi örgütlenmelerin) yayınlara verdiği desteğin, sivil kamunun (üniversitelerin ve sivil toplumdaki kuruluşların) ve hatta özel yayınevlerinin desteklerinden daha az olduğu gözlemleniyor.

Sivil toplumun yayınlara yaptığı önemli ölçüdeki katkı kayda değer bir farkındalık göstergesidir -özellikle sivil toplum oluşumlarının kaynak yetersizliklerinin ve toplumsal (veya resmi) tanınma/kabul sorunlarının güçlerini (etkilerini) sınırladığı düşünüldüğünde (Açıkalın 2017c). Sivil toplum başlığında üç küme bulunmaktadır. Birincisi, dernek ve vakıfların kendi yaptıklarını veya başkalarının yapıkları hakkındaki değerlendirmelerini kendi kuruluşları adına yayınlamalarıdır. İkincisi, meslek odaları, sendikalar, birlikler ve diğer uzman kuruluşların sahip oldukları dergilerde yayınlanan makaleler ile kendi yayınları olan 
kitaplardır. Üçüncüsü, bu kuruluşların gündem oluşturma veya gündeme giren bir konu hakkında görüş derleme, değerlendirme, çözüm üretme amacıyla düzenledikleri toplantılarda yapılan sunuşlara veya tartışmalara ilişkin yayınlardır.

Sivil toplumun yaptığı üç boyutlu katkı karşısında "bilim yuvası" olarak kodladığımız üniversitelerin yaptıkları katkının sivil toplumla aynı düzeyde kalması, kurumsal düzeyde sosyal bilgiye atfedilen önemin azlığına işaret ediyor olabilir (daha kapsamlı bir tarama ile bu bulgu da sorgulanmalıdır).

Tablo 10, yayıncılar bakımından üniversite ve sivil toplumun katkılarının birbirine yakın olduğuna işaret ederken, yazarların hangi kimlikleriyle metinlere imza attıklarını gösteren Tablo 11, sivil kamunun bu iki alanını da besleyen faillerin (eyleyicilerin -asıl aktörlerin) akademisyenler olduğunu gösteriyor. Burada kurum raporlarında yazar adı kullanılmamışsa kuruluşa göre sınıflama yaptım ve birden fazla yazar varsa ilk yazarı dikkate aldım.

Tablo 11: Metin Yazarları

\begin{tabular}{|l|r|r|}
\hline Yazar & $\begin{array}{r}\text { Metin } \\
\text { Sayısı }\end{array}$ & $\%$ \\
\hline Akademisyen & 105 & 75 \\
\hline Sivil toplum -örgütün kendisi veya temsilcisi & 18 & 13 \\
\hline Uzman (hekim, sosyal çalışmacı, gazeteci vb.) & 11 & 8 \\
\hline Merkez-yerel kuruluş -kendisi veya temsilcisi & 5 & 4 \\
\hline Toplam & 139 & 100 \\
\hline
\end{tabular}

Tablo 11'deki sonucu Tablo 10 ile birlikte değerlendirince, akademisyenlerin sivil toplumda epey aktif oldukları anlaşılıyor: Bilim insanlarının kurumlarından özerkleşerek kamusal ve bilimsel sorumluluklarını yerine getirdikleri izlenimi ortaya çıkıyor. Akademisyenlerin çeşitli kolektif aktörlerden gördükleri desteğin cılızlığı daha ayrıntılı analizlerle de desteklenirse, bilim kuruluşlarının, bireysel bilimcilerin ilgi ve sorumluluk düzeylerine cevap ver(e)medikleri çıkarsanabilir. Buna ek olarak, veri tabanındaki duruma göre, hiçbir yayının yayınevleri dışında bir özel kuruluş tarafından yaptırılmamış olması ve özel yayınevlerinin bir Van özel sayısı çıkarmamış olması da ayrıca kayda değerdir (tabii bu kaydın da dikkatlice sorgulanması gerekiyor).

\subsection{Yazarlar Arası Etkileşim: Bir Topluluktan Söz Edebilir miyiz?}

Yukarıda bireysel bilimcilerin hem sivil toplumu, hem üniversiteleri, hem de resmi kamuyu ürettikleri bilgiyle beslediklerini ortaya koydum. Bu noktadan sonra temel soru şu olabilir: Bireysel bilimciler kendi başlarına mı yoksa kolektif olarak mı iş görmekteler? Bu sorunun asıl amacı, bu makalenin başlangıcından beri işaret ettiğim bir noktayı sorgulayabilmek: Acaba depremin sosyal boyutları üzerine çalışanların bir "bilgi topluluğu" olduklarından söz edebilir miyiz? Veri tabanındaki iki ölçüte göre yazarlar arası etkileşimin niteliği ve düzeyi hakkında bir fikir edinmek olanaklı gözüküyor; bu ölçütler, metnin bireysel veya kolektif bir ürün olması ve yazarlara atıf sayıları.

Tablo 12, metnin bireysel veya kolektif bir ürün olmasını yazar sayısına göre belirliyor. Buna göre 139 metnin \%45'i bireysel olarak yazılmış. Fakat bunlardan bir kısmı ortak araştırmaların ürünü: Örneğin, Toplum Bilim Dergisi'nin Özel Sayısı'nda (2006) yer alan 11 makale ve Yüksel ve arkadaşlarının (2005) derlediği metinde yer alan sekiz makale kolektif projelere katılan bireylerce yazılmışlar. Dolayısıyla bu veri tabanında kolektif ürünlerin önemli bir yer tuttuğu söylenebilir ve bu sonuç, bilgi (veya bilim) topluluğu olma açısından olumludur. Ama bir o kadar eserin de bireysel çabalarla üretilmiş olması, topluluk içi desteklerin, iletişimin ve işbirliğinin sınırıılığını gösteriyor olabilir. 
Tablo 12: Bireysel veya kolektif çalışma

\begin{tabular}{|l|r|r|}
\hline Çalışma türü & $\begin{array}{r}\text { Metin } \\
\text { Sayısı }\end{array}$ & \\
\hline Bireysel & 64 & 45 \\
\hline Kolektif & 76 & 55 \\
\hline Toplam & 139 & $\mathbf{1 0 0}$ \\
\hline
\end{tabular}

Şimdi daha can alıcı bir noktaya geçebiliriz: Her eseri ilk yazarla temsil ederek değerlendirirsek, acaba metinler (çoğu akademisyen olan yazarlar) arasında yeterince etkileşim olduğundan söz edebilir miyiz? Atıflar (kaynak kullanımları), metinler ve yazarlar arasında birbirinden etkilenmelerin, birbirini eleştirmelerin ve yeni yol, araç ve fikir geliştirirken izledikleri veya karşı çıktıkları yaklaşımların göstergesidir. Ayrıca bilgi/bilim topluluğunun modern dönemdeki en temel ilkelerinden biri, hangi amaçla olursa olsun yararlanılan kaynakları dürüstlükle göstermektir.

Veri tabanından analize kattığım 139 metin arasında kaynakça gösteren 89 metin saptanmıştır. Tablo 13'deki dağılımlara yalnız az çok analitik metinler dâhildir (TUİK, AFAD gibi kuruluşların veri setleri sayılmamıştır). Temel ölçüt, yazarların veri tabanındaki görünürlüğüdür: Yazarlar sayılmıştır ama bir kaynakta kaç kez atıf aldıkları sayılmamıştır; veri tabanında yer almayan metinlerine yapılan atıflar ise sayılmıştır. Birden fazla yazar çoğunlukla birlikte yazdıkları metinlere atıf almışlarsa tek yazar gibi sayılmışlardır (ör., Kasapoğlu ve Ecevit), fakat çeşitli eserlerinde ortak yayın yapmamışlarsa ayrı ayrı gösterilmişlerdir (ör., Akşit'in iki ve Karancı'nın altı eserinde bu iki yazar ortak değildir).

Tablo 13: Kaynak Kullanımları

\begin{tabular}{l|r|}
\hline Yazarlar & $\begin{array}{r}\text { Atıf yapılan } \\
\text { kaynak sayısı }\end{array}$ \\
\hline Kasapoğlu ve Ecevit (1) & 24 \\
\hline Karancı & 20 \\
\hline Akşit & 15 \\
\hline Başoğlu ve Şalcıoğlu (2) & 8 \\
\hline Yüksel, Sercan, Sezgin ve Gökalp (3) & 8 \\
\hline Ergünay & 8 \\
\hline Yucak & 6 \\
\hline Diğer yazarlar (1-4 kez kaynak gösterimi) -32 yazar & 53 \\
\hline Yabancı yazarlardan kaynak gösterilenler -6 yazar (4) & 25 \\
\hline (1) İki eser yalnız Kasapoğlu'na ait & \\
\hline (2) Bir eser yalnız Başoğlu'na, biri yalnız Şalcıoğlu'na ait & \\
\hline (3) Aynı cildin içinde yalnız Yüksel'e ve yalnız Sercan'a ait ikişer metin & \\
\hline (4) İki isimli bir eserde ilk isim Türktür, fakat yayınevi uluslararasıdır ve eserin “yabancılar” kümesindeki \\
görünürlüğ daha fazladır. Bu nedenle bu yazar bu kategoride kodlanmıştır.
\end{tabular}

Öncelikle, Tablo 13'te veri tabanındaki 139 metinden kaynakça gösteren yalnız 89 metin (\%64) bulunması hakkında bir kayıt düşmek gerekir. Bu durum deprem çalışmalarının uygulamalı boyutunun ağır basmasından etkilenmiştir. Buna rağmen 17 yılda ulaşılan bu oran analitik metinlerin yetersizliğini göstermektedir. İkincisi, ulusal yazında yalnız üç yazarın görünürlügünün göreli daha fazla olması (15-25 atıf) ve kendisine beşten fazla metinde atıf 
yapılan yedi yazar olması, deprem çalışmaları alanında ürün ortaya konurken ilgili yazından yeterince yararlanılmadığına işaret etmektedir (bilimin "dürüstlük" ilkesine uyulduğu varsayımı altında). Oysa diğer yazarlar arasında kıymetli fikirler ve bulgular ortaya koyanlar ve aslında tematik veya metodolojik yönden aynı kümede toparlanabilecekler bulunmaktadır (Açıkalın 2017a). Üçüncüsü, tabloya yansımamış olmakla birlikte, beşten fazla metinde atıf alan yazarların da değerli modellemeleri veya bulguları pek kullanılmamaktadır; bunlar daha çok "adet yerini bulsun" diye kaydedilmiş izlenimi vermektedir. Örneğin, Karancı'da (2009) duygu/akıl odaklı davranış ile kaynak sahipliği arasındaki ilişki, Akşit'teki (2003) beş unsurlu toplumsal yapı modellemesi, Kasapoğlu-Ecevit'te (2002) deprem deneyiminin kültüre dönüşmesi fikri (ve bu yöndeki bulgular) üzerine düşünüldüğüne ilişkin kanıt çok azdır. Kısacası yazına başvuru genelde zayıf ve ulusal kaynakları kullanmaya isteklilik düşüktür. Kaynakların bir kısmındaki fikir benzerliği ilginçtir; ama bazı metinlerde fikirleri orijinal kaynağa doğru izlemek mümkün olamamaktadır. Dolayısıyla bir bilim/bilgi topluluğundan söz etmek güçtür.

Buna karşılık uluslararası kaynaklarda yayınlanan eserleri kullanmaya isteklilik epey yüksektir. Oysa bunların da arasında kalitesi düşük ve yüksek olanlar, hatta birinde kaynak gösterilmemiş bir Türkçe metni çağrıştıran özellikler de bulunmaktadır. Atıf alan altı yabancı yazarın hepsi, yabancı bir yazar tarafından yazılan ilk (çekirdek) kaynağa ve kendilerinden önce yayın yapmış diğer yabancı kaynaklara atıfta bulunmuşlar; böylece bir ilgi alanı ve gündem oluşmasına katkıda bulunmuşlardır (bir topluluk bilinci göstergesi). Bu metinlerin bir kısmında 2002-2010 arasında, Marmara-sonrasındaki ilk dönem ile ikinci dönemin ilk yarısına ait sınırlı ve benzer verilerle deprem geri planında Türkiye demokrasisi yorumlanmıştır. Ancak asıl vurgulamak istediğim nokta, "çekirdek kaynak"ta ortaya konan Türkiye temsilinin yıllar boyunca az çok tartışılarak kısmen değiştirilmiş, kısmen de zenginleştirilmiş olmasıdır (bilim topluluğu göstergesi). Üzerinde durulması gereken ikinci nokta ise, ulusal metinlerde de bunlara atıf yapma istekliliği yüksek olmakla birlikte, bunlardaki fikirleri sorgulama kapasitesine sahip olan ulusal metinlere ilgi gösterilmemiş olmasıdır (Açıkalın 2017a). Son olarak, yazına önemli katkısı olabilecek bir metinde İngilizce kaynak sıkıntısının dile getirildiğini kaydetmeliyim. Bu konuda bilim topluluğunun sorumluluk üstlenmesinin daha doğru olacağını düşünüyorum, çünkü çeviriler ancak kurumsal olarak üstlenilirse sistematik ve kaliteli olabilir (bireysel çabalarla yaptırılan çeviriler, konuya hâkim birinin denetiminden geçmediğinden, yer yer okunmayacak kadar düşük kalitede olabiliyor).

\section{Sonuç}

Depremin sosyal boyutları üzerine çalıştıkça, az çok sistematik bir sorgulamayla deprem bölgelerindeki durum hakkında kabaca malumat edinmemizi bile sağlayan her metnin yazına katkıda bulunduğunu daha iyi anladım. Fakat artık araştırma prosedürünün "usulünce" tanıtımını ve tanıtılan prosedüre uyulmasını, iddialar ve bulgularla teorilerin ilişkilendirilmesini talep edebilmeliyiz.

$\mathrm{Bu}$ makale boyunca, çokça metot alanında ve biraz da bilgi sosyolojisinin sınırlarında dolaşarak Türkiye'ye ilişkin sosyal boyutlu deprem çalışmalarının özelliklerini ve belirgin bazı sorunlarını irdeledim. Bu iş için 2000-2017 arasında yayınlanmış 139 metinden yararlandım; bu kaynakları daha önce oluşturduğum bir veri tabanından derledim. Veri tabanını oluştururken kullandığım amaçsal ölçütlerden dolayı bulgularım istatistiksel bakımdan genellenebilirlik niteliği taşımıyor ama örüntüler hakkında fikir veriyor.

$\mathrm{Bu}$ makale sosyal bilgi üretenlerin konuya ilgisinin kriz dönemlerinde arttığına ve kriz yaşamayan mekânlara meraklarının zayıf olduğuna işaret ediyor: Veri tabanının \%43'ünü oluşturan Marmara ve \%30'unu oluşturan Doğu dışında Türkiye'de sosyal yönden çalışıımış bir "deprem bölgesinden" söz edemeyiz. Deprem tehlikesi yüksek olup bu iki bölgenin dışında kalan illere ilişkin çalışmalar veri tabanının üçte birine ancak ulaşıyor, ama onlar da sistematik olarak çalışılmamış ve karşılaştırmaya uygun değiller. Üstelik Marmara'da bile 
yöreler, iller ve toplumsal kesimler düzeyinde karşılaştırma yapabilecek bilgimiz çok sınırlı: Özgül mekânı belirlenmemiş (genel) ve yalnız Düzce hakkında bilgi üreten metinler Marmara çalışmalarının \%45'ini kaplarken, diğerlerinin ilgisi çeşitli mekânlara, dönemlere ve konulara yayılmış. Doğu bölgesinde ise veri tabanına kayıtlı 40 metnin \%85'i Van kentiyle ilgili; Erciş dâhil diğer yöreler pek ender çalışılmış. Deprem sonrasının ikinci aşaması olan iyileşme dönemi veri tabanının üçte birinden fazlasını kaplarken, diğer üç dönemin (akut/acil yardım, yeniden yapılanma ve hazırlık) her birinin kapladığı alan dörtte veya beşte birde kalıyor.

Özetle, farklı mekân ve zamanlarda ama aynı deprem sonrası dönemde, aynı konu/tema ve aynı toplum kesimi (veya aynı dönem-yer-konu ama farklı gruplar) üzerine aynı tür veri toplanıp analiz edilmemiş. Bir deprem bölgesinde farklı dönemlerde aynı grup ve aynı katılımcılar da çalışılmamış. Böylece 2017 itibariyle, depremin sosyal boyutlarını etraflıca anlayabileceğimiz bir Türkiye temsiline ulaşamamışız. Bilimin temeli olan sınıflama ve karşılaştırma olanaklarını yeterince yaratamamışız. "Neden ve nasıl oluyor da hâlâ depreme dayanıklı bir toplum haline gelemedik?" sorusuna cevap verebilecek kavramlar ve kuramlar geliştirememişiz. Bunların yerine ortaya kabaca şöyle bir betimleme çıkarmışız: Depremden sonra bireyler dert çekmişler; toplum büyük bir dayanışma göstermiş; bireylere göre devlet onlara yeterince yardım etmemiş, fakat devlete göre olabilecek her olanak fazlasıyla verilmiş; en sonunda (ama aslında kısa sürede) herkes deprem hiç olmamış ve artık hiç olmayacakmış gibi davranmaya başlamış. Bu düzeyde bilgilenmeyle durumu ne etraflıca anlamak ne de değiştirmek olanaklı.

Ortaya koyduğum tablo, sosyal boyutlu deprem çalışmaları alanında iki temel soruna dikkat çekiyor. Bunlardan birincisi konular bakımından dağınıklık ve yetersizlik, ikincisi ise konuların ele alınışı bakımından düşük kalite. Bu iki sorunu da bireylerin teknik araştırma bilgi, beceri ve sorunlara yönelik ilgi eksikliği ile açıklayabiliriz. Fakat bulgular bu yaklaşımın daha derindeki sorunları görmemizi engelleyeceğine işaret ediyor.

İlk mesele olarak yazındaki dağınıklık ve yazının yetersizliği kapsamında iki boyut beliriyor: Sorunların bütünlüklü ve sistemli bir yaklaşımla irdelenmemesi ve depremlerin etkilerine odaklanıp nedenlerini çözümlemeye, dolayısıyla depreme hazırlık aşamasına ilgisizlik. Bulgular aslında bireysel bilimcilerin ve diğer uzmanların konuyla ilgilendiklerini, fakat araştırmalara kamusal desteğin kurumlaşmadığını gösteriyor. Örneğin, veri tabanındaki metinlerin yazarlarının yarıya yakını bireysel olarak yayın yapmış. Sosyal bilgi içeren ürünlerin yayınını kamu kuruluşları pek az desteklemiş ve üniversiteler ile kaynak yetersizliğiyle tanıdığımız sivil toplum yayınlara birbirine yakın düzeyde katkıda bulunmuşlar. Özel sektör ise yalnız yayınevleriyle temsil edilmiş ve katkısı düşük düzeyde kalmış. Böyle bir ortamda bireylerin katkılarının sistematik hale gelmesi, hele ki etkilerin belirleyenlerine yönelmesi güçtür. Bunun yerine kriz anlarında ve önemli mekânlar zarar gördügünde zararın yarattığı etkilere odaklanılması, aynı zamanda sorunsalın kurgulanmasında bağlamın etkisinin artması en beklendik durumlar olmaktadır.

Bu çerçevede sosyal bilimcilerin dağınıklığını ve kolektif enerjilerini bir gündem yaratmaya yönlendirmemelerini kısmen bir farkındalık sorunuyla ilişkilendirsem bile, daha çok kurumsal düzeydeki farkındalık eksikliğine bağı olarak ortaya çıkan destek yetersizliklerini vurgulama eğilimindeyim. Farkındalık eksikliği, sosyal bilginin sorunların çözümünde taşıdığı önemin anlaşıımamasıyla ilgilidir ve bu fikrin bir adım gerisinde, teknik bilgiye duyulan aşırı güven durmaktadır (Açıkalın 2017c, 2018).

İkinci mesele olan kalite sorununun ise, bilimsel bilgi üretmenin en temel kurallarının yeterince bilinmediği veya uygulanmadığı; uygulamaların da denetlenip düzeltilmediği (belki kimsenin pek umurunda olmadığı) için ortaya çıktığı kanısındayım. Pozitivist gelenekle tanışıklık, nicel ampirik araştırmaların çoğunda bariz teknik hataları azaltsa bile (ör., prosedürün tanıtımı, örneklem seçimi, iki değiş̧enli analiz, bulguların raporlanması), teoriyle ilişki ve dolayısıyla yer yer değişken tanımları bile sorunlu olmayı sürdürebiliyor. Pozitivist gelenek gibi diğer gelenekler de yeterince bilinmediğinde ise kalite sorunları çeşitlenip 
derinleşiyor. Dolayısıyla eğitim sistemine ve akademik yapılanmanın özelliklerine de işaret eden şekilde bilgi eksikliğinin sürmesine ve derinleşmesine yol açan önemli bir neden olarak, Türkiye'de bilim topluluklarının genelde zayıflaması ve/veya deprem çalışmaları alanında bu tür bir topluluğun henüz oluşmamış olması üzerinde durmak gerekiyor.

Üçüncü olarak bağlamın etkisinden söz etmek gerekiyor. Bağlam yalnız depremzedeyi veya sivil toplumun, devletin ve medyanın ilgilerini etkilemez; aynı zamanda, tüm bu unsurların ve süreçlerin bilgisine sahip olmasını (bu bilgiyi üretmesini) beklediğimiz bilim çevrelerinin de ilgilerini ve yaklaşımını belirler. Bu çerçevede, Marmara'ya yönelttiğimiz, Van'da düzeyi düşen, Türkiye'nin diğer deprem bölgelerinden ise neredeyse tümüyle esirgediğimiz ilgimizi öncelikle iki faktöre dayanarak açıkladım: Bir bölgedeki yıkımın (krizin) büyüklüğü ile o bölgenin nüfusu ve ekonomisiyle ülke açısından taşıdığı önem. Üçüncü bir unsur olarak ise konjonktürün etkisine değindim: Marmara depremleri, bir sivil uyanışa ve onu destekleyen ulusal ve küresel ortama denk gelerek, depremle ilgili bilimsel çalışmalara altık oluşturmuş, bilim gündemini epey etkilemişti. Ulusal ana akım medyada ve uluslararası bilim camiasında deprem dolayımıyla Türkiye'deki demokratikleşme potansiyeli bu bağlamda tartışılmıştı. Oysa Van depremleri, sivil uyanışların tepe taklak gidişinde kritik bir dönemeçte gerçekleşmişti. Üstelik Van deneyimi AFAD ve belediyelerin örgütsel ve teknolojik donanımlarıyla yeterliliklerini kanıtladıkları bir örnek olarak sunulmuş, sonraki yıllarda da bu imge desteklenmişti. Ayrıca gelişmekte olan bir ülkenin küresel neo-liberal rejim içinde var olma biçiminin etkisiyle, "üretmeden büyüme" stratejisine uygun bir araç haline getirilen kentsel dönüşüm Türkiye'nin depreme hazırlığı açısından "ana sorun" olarak belirlenmişti. Bu bağlamda devletin ve ana akım medyanın yönelimleri kadar küresel süreçler de ilgimize destek veya kaldıraç olamamışlardı (Açıkalın 2017b, Açıkalın ve Çiftçi 2018).

Geriye bilgi/bilim topluluklarının kendi enerjilerine dayanarak inisiyatif geliştirmeleri, özmerkezli hareketlenmeleri ile program ve gündem oluşturup, bağlamın karşıtığına rağmen bunları depreme dayanıklıık-dirayetli toplum yönündeki dönüşümde kullanmaları kalıyordu. Oysa depremin sosyal boyutlarıyla uğraşanların yakın zamana kadar kendileri gibi ürettikleri bilgi de parçalı yapıda olduğundan dolayı, bilgi topluluğunun bu tür bir iç dinamizmi, gücü ve istekliliği yoktu. Ama umuyorum ki yakın zamanda alternatif adımların sayısı ve bu adımlarla kat ettiğimiz mesafe artacak. Bu makalenin yayınlandığı Van derlemesi bu adımlardan biridir.

Kısacası, sorunları daha çok yapısal düzeyde tanımlayıp, çözümün kolektif eyleyicilerin örgütlü, planlı, sabırlı ve uzun soluklu mücadelesiyle olanaklı olacağını söylüyorum. Bu çerçeveye rağmen, burada, pragmatik bir yaklaşımla birkaç basit öneri sunarak, konuyla samimiyetle ilgilenen araştırmacı ve eğitmenlerin işine yarayabilecek bazı noktaları da kaydetmek istiyorum. Bunları veri tabanındaki metinlerden örneklerle somutlaştırmak ise ayrı bir makalenin konusu olabilir.

Depremzedelerin yaşamına ilişkin her türlü ayrıntıyı çeşitli boyutlarıyla ve derinlemesine "anlamak" istiyorsak, zamanla (deprem-sonrası hangi dönem), mekânla, bireylerin/grupların özellikleriyle, deprem deneyimleriyle ve hepsini sarıp sarmalayan koşullarla (yapılarla) ve bağlamla ilgili bilgileri edinmeli ve okura aktarmalıyız. Bu kapsamda şu üç boyut birbiriyle ilişkilidir: Araştırma nesnesinin (ör. depremzedeler, yöneticiler veya STK'lar) içinde oluştuğu zaman-mekân-koşullar-bağlamla etkileşimleri, bu unsurlara yüklediği anlamlar ve araştırmacının bu oluşumları nasıl kullandığı-kurguladığı (veya neyin peşinde olduğu). Bu boyutlar aracılığıyla, araştırmacı ve araştırılan farklı düzlemlerde özne ve nesne konumları alarak birbirlerini etkiler ve bu etkileşimli süreçte yapılar-kurumlarla da etkileşirler (Danermark vd. 2013; Donati ve Archer 2015). Bu çerçevedeki işleyişi bizim için anlaşılır kılan teorilerdir. Bu bakış açısıyla, belirgin olan veya olmayan fikirlerimizin, bir tekniği veya teknikler kümesini araştırmaya katıp katmamamızın veya bir işi belli bir kurala uygun yapıp yapmamamızın, "gerçekliğin" "öyle" veya "böyle" görünmesini (temsilini) etkilediğini anlayabiliriz.

Burada (öz)düşünümselliğin yararlarını vurgulasam bile, biliyoruz ki depremzedeler de araştırmacılar da az ya da çok yanlı ve kısmî olabilirler, her şeyi "en doğru ve yeterli" 
düzeyde izleyip bilemezler. Bu konudaki çetrefil tartışmalar bir yana, ben çok basit bir iki noktaya dikkat edilmesini öneriyorum: İzlenim, duygu, tutum ve hatta davranışlara ilişkin bildirimler belirli sorular için önemliyken, bazıları için yanıltıcı veya yetersiz olabilir. Bu bakımdan ne tür bilgi için katılımcıların görüşüne veya kapsamlı hazır veriye intiyaç duyulduğunu ayrıştırmak gerekiyor.

Ampirik veri toplamak istediğimizde, örnek seçme tekniklerinin kullanımına özenmek, konu gerektirdikçe anket dışındaki veri toplama araçlarına (da) yönelmek, alandan hızla ayrılmamak, veri toplayanların ve analistlerin teknik ve etik eğitimini gerçekten önemsemek alabileceğimiz asgari tedbirler arasındadır. Anket ve derinlemesine görüşmelerde hangi soruyu kime nasıl yöneltmemiz, neyi kast ettiğimizi ve katılımcıların (soruyu sorduklarımızın) sözlerimizi nasıl anlayabileceğini veya hangi grubu nasıl gözlemlememiz gerektiğini sorgulamalıyız. Görüşmelerde tüm dikkati o anki iletişime toplamalı, karşımızdaki insanı olabildiğince onun bakış açısından görmeli, kendimizi katılımcıdan daha önemli/akılı/bilgili görmemeliyiz. Depremzedelerin öznelliklerini anlamak için gereken duyarlılığa ulaşabilmek için önce kendi öznelliklerimizin farkına varmayı deneyebiliriz. Bu özellikleri kazanmanın yolu yeterince bilgilenmenin yanı sıra, başlangıç düzeyi metot derslerinde anlatıldığı üzere, kaliteli bir rehberlikle ekip çalışması, görüşmeci (görüşmeyi yapan) eğitimi ve pilot çalışmadır. Ayrıca hanede bir kişinin veya hep aynı kategorinin temsilcilerinin (ör., yetişkin erkekler veya mesai saatlerinde evde bulduğumuz kadınlar) görüşlerine dayanarak (bireyin temsiliyle) hanenin sorunlarını saptadığımızı düşünmemeliyiz; sistematik hata yapma risklerimizi değerlendirmeliyiz. Ancak burada örneklediğim türde ayrıntılı tedbirleri sabırla alırsak, görünüşte çok önemsediğimiz depremzedeleri, araştırmalara özne konumunda katma olanağını yaratırız.

Her dönemin kendine özgü yanları ve içsel dinamikleri vardır; bu nedenle her dönemi titizlikle çalışmak önemlidir. Fakat aynı zamanda ne kadar çok dönem birbirlerine geçişliliğiyle içerilirse, o kadar bütünlüklü bir analiz ortaya çıkar ve ilişkisellikleri gözlemlemek veya kurgulamak olanaklı olur. Bunun nedeni, depremzedelerin de, toplumsal kesimler, sivil toplum veya deprem yönetimlerinin de her dönemde farklı konulara odaklanması; hepsinin iyisiyle kötüsüyle süreçte değişmesi; dolayısıyla, yapılarla-kurumlarla aktörlerin-pratiklerin (eyleyicilerin-eylemlerin) etkileşimlerinin de değişerek, birbirlerini etkileyerek sonuçları farklılaştırmasıdır. Değişmeyi betimlemenin de, neleri nasıl etkilediğini saptamanın da yolu, zaman boyutlu araştırma yapmaktır.

Dönemlere göre araştırılması gereken pek çok konu bulunmaktadır. Öncelikle akut döneme (acil yardım dönemine) önem verilmelidir. Tüm etkilenen yerleşimlerde (ör., kırsal ve kentsel; kenar mahalle veya kent merkezi) geçici barınma, beslenme, psikolojik destek, hijyen, sağlık, güvenlik, göç gibi koşulların ilk 15-20 gündeki değişimlerini farklı toplum kesimleri için sistemli şekilde izleyip, sonuçları kamuyla paylaşmalıdır. Bunu, akut dönemin ağır yüküyle uğraşan kamu kuruluşlarının yapması olanaklı değildir; buna hazır sivil kuruluşlar olmalıdır ve bilim toplulukları bu konuda liderlik üstlenmelidir. İyileşme döneminin ikinci altı ayında sorunlara ilgi azalmaktadır. Oysa bu dönemdeki gelişmeler (göçler, geri dönüşler, çadırlarda kalmayı sürdürenler, konut yapımları, ekonomisi veya psikolojisi toparlanamayanlar vb.) giderek çeşitlenmektedir. Benzeri şekilde yeniden yapılanmanın barınmaya, sağlığa, eğitime, güvenliğe, refaha, aile-kenttaş ilişkilerine ve depreme hazırlığa ilişkin boyutları vardır.

Depreme hazırlıkla ilgili etkinliklerin sonuçlarını gözlemleyen araştırmalar neredeyse hiç yoktur. Bu durum depreme hazırlık kültürünün oluşup oluşmadığını araştırmacıların da yeterince önemsemediklerine işaret eder. Oysa bu konu önemsendikçe hem her dönemde hazırlığa ilişkin ipuçları ilgi çekici bir araştırma konusu olacak, hem de sonuç odaklı olabilmek (ör., dolaplar sabitlendi mi, engelliler tahliye denemesine katıldı mı gibi sonuçlar) için süreç odaklı yaklaşım gelişecek. Yani bilgi edinmeyi, bireysel olmaktan çok toplumsal, tek yönlü olmaktan çok etkileşimli, verilen bir şey olmaktan çok edinilen, deneyimle ilgili bir şey olarak (kısacası bir kültür olarak) kurgulayabileceğiz, deneyimleyebileceğiz. 
Bu kadar çeşitli konunun varlığı ve her konudaki hızlı değişmeler bireysel araştırmacılar kadar araştırma programı-gündemi olmayan gruplar ve kuruluşlar için de dikkat dağıtıcıdır. "Gündemsizlik," en çarpıcı olan etkiler konusuna odaklanılma eğilimini artıran bir faktördür. Yapılması gereken, belirli bir araştırma programına dayanan bir gündemle tüm bu "dallıbudaklı" konuları birbirleriyle ilişkilerine de önem vererek belirli aralıklarla sistematik şekilde araştırıp izlemek, analizleri hızla tamamlayarak kamuyla paylaşmaktır. Konu, kritik dönemlerde uygulamalı araştırmalara ağılık verilmesini, kriz dışı dönemlerde ise bu tür araştırmaların bulgularına dayanarak temel araştırmalara odaklanılmasını gerektirmektedir. Dolayısıyla dayanıklılık kazanma (dirayetli toplum olma) sürecinde örgütlü ve gündemli çabanın yöneleceği alanda araştırma ve uygulama iç içedir; birbirleri kurarken yeni bir bütünlük olarak ortaya çıkan dirayetli toplumun da oluşumuna katkıda bulunmaları bakımından ilişkiseldir.

Tüm bu aşamalarda bilgiyi önemseyen sivil toplum oluşumlarının işbirliği ve bilim topluluklarının liderliği, üretilecek bilgiyi kaliteli ve işe yarar kılacaktır (Açıkalın 2017b, c). Resmi kamu bilim topluluklarını ve sivil toplumdaki uygulamacıları başlıca üç yolla destekleyebilir. Bunlar, sivil toplum oluşumlarının çalışma isteklerini olumlu karşılamak, kendisinin sahip olduğu bilgiyi paylaşmak ve yapılan işlere kaynak desteği sağlamaktır. Resmi kamunun elindeki veri yığınından kullanılabilir veri setleri oluşturup veri bankasına yerleştirmek için bilim çevreleriyle işbirliği yapması gerekmektedir, çünkü taşra teşkilatlarının çoğunda yalnız bu işlerle ilgilenebilecek kadar ve uygun kapasitede personel bulunmayabilmektedir. Ancak bu tür işbirlikleri için resmi kamunun da sosyal bilginin önemini anlaması, benimsemesi ve bu bilgiye dayanarak geliştirilmesi muhtemel eleştirileri düşünerek (özgüven yoksunluğuyla) geri çekilmemesi gerekmektedir.

Yukarıda sıraladığım konuların yanı sıra, köyler hep inmal edilegelen bir konu olmuş; TOKI'ler rasgele çalışılmış; sivil toplum ise yalnız Marmara bağlamında irdelenmiştir. Toplumsal kesimler arasında etkilenme farkları ve benzerlikleri ile bunların nedenleri üzerinde de yeterince durulmamıştır. Deprem yönetimi konusunda ampirik araştırmalar gerekmektedir. Örneğin örgütlenme şemalarında veya mevzuatta belirlenen özelliklerin farklı dönemlerde somut örgütler (AFAD, belediyeler vb.) içinde hangi ölçüde, hangi koşullarda veya ne yönden işlediğini veya işlevsiz kaldığını değerlendirmek; yöneticilerin veya çalışanların görüşlerini ve deneyimlerini derlemek, betimlemek ve yorumlamak gerekmektedir. AFAD'ın merkez ve taşra teşkilatlarının yürürlükteki mevzuatı uygulama biçimlerini, bu teşkilatların ilişkilerini veya bunların halkla ilişkilerini eleştirel bakışla irdeleyen bir metin bile yoktur. Mevzuat değişiklikleri bağlamında belediyelerin örgütlenme biçimlerinde, devletin merkezi ve yerel teşkilatlarıyla veya halkla ilişkilerinde ortaya çıkan/çıkmayan değişimler de pek çalışılmamıştır. Bu örnekler araştırma konularındaki eksiklerin yalnızca bir bölümüdür; bunları sıralamamın nedeni, bütünlüklü bir araştırma programının hazırlanması gerektiğini vurgulamaktır.

Sistemli karşılaştırmalar yapmadan anlamlı ve işe yarar bilgi üretilmez. Acaba son iki yıldır hangi iller veya yöreler hakkında ne tür araştırmalar yapılmıştır? Bunun güncel takibi için bilimsel ağlarımızı genişletip ilişkilerimizi canlandırmamız gerekir. Kurulan az sayıdaki veri tabanı (ör., ODTÜ'nün AFAD'a devrettiği ve benimki) birleştirilmeli ve sürekli güncellenebilecek bir yapılanma oluşturulmalıdır. Ayrıca bir veri bankası kurulmalıdır. Umuyorum ki 2017 sonunda yayın hayatına başlayan Dirençlilik/Resilience Dergisi, bu alanda çalışanların birbirlerini tanımalarına, aralarındaki iletişimin sistematik hale gelmesine ve atılacak kolektif adımlara katkıda bulunan bir ortam sağlar.

Özetle konuyu gündemleştirmek ve konunun etkiler düzeyinde analizinin ötesinde dayanıklılık/direnç/dirayet kapsamında analizini teşvik etmek için bilim topluluğunun hem kendi içinde hem de ilgili diğer aktörlerle (başlama noktasına sivil toplumu koyarak) işbirliği içinde desteklerini kurgulaması ve kurumlaştırması gerekmektedir (Açıkalın 2017b). Bu ilişkilerin kurgulanması gerilimli, mücadele içeren ileri-geri adımları içeren sancılı bir süreç olacaktır. Ama "ilişkisel özne" oluşun bir gereği de (öz)düşünümsel-eleştirel yaklaşımla 
eşitlikçi-kapsayıcı çözümlere katkıda bulunmak olarak düşünülebilirse, kolektif eylemle zorlukları yenmeyi hedeflemek en gerçekçi çözüm önerisi olarak görünmektedir (Açıkalın 2017c; Açıkalın ve Çiftçi 2018).

Nihayetinde; Afrika Anadolu plakasına ve Anadolu Avrupa plakasına yapışma yönünde hareketini sürdürmektedir. Milyonlarca yıl alacağı öngörülen bu süreçte yalnız İstanbul'da değil, Anadolu'nun çeşitli yerlerinde büyük ve şiddetli depremler olacaktır. Kentler büyümekte, nüfus yapıları ve yaşam biçimleri değişmekte, mekânsal-toplumsal sorunlar karmaşıklaşmaktadır. Dolayısıyla dünya ve dünyada insanlık ortadan kalkmadığı müddetçe sosyologların ve tüm sosyal bilimcilerin kapasite geliştirmeleri işe yarayacaktır.

\section{Kaynakça}

Açıkalın, Oya. 2017a. Deprem Bağlamında Dirayetli Toplumun Neresindeyiz? Yüzyılın Hesabı. Yeni İnsan Yayınevi: İstanbul.

Açıkalın, Oya. 2017b. "Civil Society and Disaster Resilience in Turkey" (Un)Making Europe: Capitalism, Solidarities, Subjectivities, 13th Conference of the European Sociological Association, 29 Aug-1 Sept., Atina -Yunanistan, www.esa13thconference.eu.

Açıkalın, Oya. 2017c. "Earthquakes and Society: Rethinking and Rebuilding Our Relations with Knowledge" Advances in Social Science Research Journal 4(25): 146-156. Dol: 10.14738/assrj.425.4040

Açıkalın, Oya. 2018. "Bilim Toplulukları ve Sivil Toplum İşbirliğiyle Türkiye'de Depreme Dayanıklılık," (Earthquake Resilience in Turkey by the Cooperation of Scientific Communities with Sivil Society) 20. Yuvarlak Masa Toplantısı, 16 March 2018, ODTÜ Afet Merkezi, Ankara.

Açıkalın, O. ve Çiftçi, Yahya. 2018. "Deprem, Bilgi ve Toplum," (Earthquakes, Knowledge and Society), 71. Türkiye Jeoloji Kurultayı, 25-27 April 2018, ODTÜ Kültür ve Kongre Merkezi, Ankara.

Afet ve Acil Durum Yönetimi Başkanlığı (AFAD)-Van Valiliği. 2012. Depremden sonra 120 gün... Van Depremi. AFAD-Van Valiliği: Van.

Akşit, Bahattin. 1997. "Sosyoloji," Cumhuriyet Döneminde Türkiye'de Bilim, Sosyal Bilimler içinde ss. 7-18. Türkiye Bilimler Akademisi (TÜBA): Ankara.

Akşit, Bahattin, Serdar, Ayşe ve Tabakoğlu, Bahar. 2003. Sivil Toplumun ve Katılımın Güçlendirilmesinde Sivil Toplum Kuruluşlarının Rolü. TÜBITAK-TÜBA-YÖK SOBAG Araştırma Raporu: Ankara.

Altıntaş 2012. "Kentsel Dönüşüm Sürecinde İktidarın Meşrulaştırıcı Söylemi: Depremin Hegemonik Şiddeti," Birikim. http://www.birikimdergisi.com/guncel-yazilar/434/kentseldonusum-surecinde-iktidarin-mesrulastirici-soylemi-depremin-hegemonik-

siddeti\#.WICaQtKLTs0

Balamir, Murat. 2000. "Kaderci Toplumun Yeniden Üretimi: Türkiye Afetler ve İmar Mevzuatının İrdelenmesi," ss. 100-125. Der. E. M. Komut. Kentsel Yerleşmeler ve Doğal Afetler. Mimarlar Odası: Ankara. 
Danermark, Berth, Ekström, Mats, Jakobsen, L. ve Karlsson, J. 2003/2018. Toplumu Açıklamak: Sosyal Bilimlerde Eleştirel Realizm. Çev: Ümit Tatıcan. Phoenix: Ankara.

Donati, Pierpaolo ve Archer, Margaret S. 2015. The Relational Subject. Cambridge University Press: Cambridge.

Fuller, Steve. 1991. Social Epistemology. Indiana University Press: Bloomington, First Midland Book Edition.

Karancı, Nuray A. 2009. "Psychosocial Aspects of Disaster Risk Management," ss. 41-66. Der. P. Gülkan, E. Başbuğ ve B. Burçak. Perspectives in Disaster Management. Middle East Technical University: Ankara.

Kasapoğlu, Aytül ve Ecevit, Mehmet. 2002. Doğu Marmara 1999 Depreminin Sosyolojik Araştırması: Hasarları Azaltma ve Toplumu Depreme Hazırlıklı Kılma. Sosyoloji Derneği Yayınları: Ankara.

Kasapoğlu, Aytül (der). 2016. Uygulamalı İlişkisel Sosyoloji. Yeni İnsan Yayınları: İstanbul.

Köktürk, Erol ve Köktürk, Erdal. 2007. "Deprem ve Kentsel Dönüşüm İlişkileri," JeodeziJeoinformasyon Arazi Yönetimi Dergisi 97: 57-64.

Kundak, Seda. 2017. "Radix of Resilience," Journal of Resilience (Dirençlilik Dergisi) 1(1): 55-69.

Restivo, Sal ve Loughlin, Julia. 1987/2010. "Eleştirel Bilim Sosyolojisi ve Bilimsel Geçerlilik," Der. Bekir Balkız ve Vefa Saygın Öğütle. Bilim Sosyolojisi İncelemeleri içinde ss. 541-564. Doğu Batı Yayınları: İstanbul.

Toplumbilim. 2006. Deprem Özel Sayısı. No: 21. İstanbul.

Türkiye Sağlıkı Kentler Birliği (TSKB). 2012. Sağlıklı Kentleşme ve Kentsel Dayanıklııı. Konferans Kitabı. Trabzon Buluşması, 3-5 Mayıs 2012, TSKB: Bursa.

Varol, Nehir ve Buluş Kırıkkaya, Esma. 2017. "Afetler Karşısında Toplum Dirençliliği," Dirençlilik Dergisi (Journal of Resilience) 1(1): 1-9.

Yüksel, Şahika, Sercan, Mustafa, Sezgin, Ufuk ve Gökalp, Peykan G. 2005. Bir Depremden Sonra... Bir Depremden Önce... ADEPSTEP. Bağımsız İletişim Ağı IPS İletişim Vakfı: İstanbul. 